\title{
Salgın ve Demografi: Yaş Gruplarına Göre COVID-19 Pandemisine Yönelik Algı ve Tutumlar ${ }^{1}$
}

\section{Öz}

Aralık 2019'dan itibaren küresel gündemin ana konusu olan COVID-19 pandemisi, etkileri ile sosyal, siyasal, ekonomik açıdan dünya tarihinin önemli bir dönüm noktası olmuştur. Yakın tarih itibarıyla daha önce tecrübe edilmeyen, dünya genelinde okulların, ticarethanelerin, ibadethanelerin kapalı tutulduğu, insanların evlerinde kalmaya mecbur kaldığı bir durumun insanlar üzerinde çok farklı açılardan etkileri olmuştur. Devletler de bu süreci yönetmek için çeşitli stratejilerle sağlık, ekonomi, eğitim, gibi alanlarda çeşitli politikalar geliştirmiştir. Bu politikaların, bireylerin ve toplulukların tutumlarının ilgili ülkenin sosyolojik, idari, kültürel, ekonomik yapısına göre farklılaşan etkileri mevcuttur. Salgının küresel ve yerel ölçekte etkilerinin yanı sıra bireylerin ve toplumların gündelik hayatına etkileri de ayrıca ele alınmalıdır. Bu düşünceden hareketle hazırlanan Koronavirüs Salgın Süreci: Alg1 ve Tutum Anketi 37,292 kişinin katılımıyla gerçekleştirilmiştir.

$\mathrm{Bu}$ araştırmanın verilerine dayanarak hazırlanan bu makalenin amacı COVID-19 pandemisine yönelik algılar ve tutumlar konusunda yaş gruplarına göre farklılık olup olmadığını incelemektir. Anket katılımcılarının cevapları SPSS programında analiz edilmiş ve yaş gruplarına göre karşılaştırmalı olarak incelenmiştir. Makale salgının halk nezdindeki tıbbi olmayan etkilerini anlama ve anlamlandırma çabalarının bir parçası olarak da yorumlanabilir.

Araştırma sonuçlarına göre COVID-19 pandemisine dair algı, tutum ve davranışlarda yaş grubuna göre büyük farklılıklar olmadığı ancak salgının olumsuz psikolojik etkilerinin gençlerde daha fazla hissedildiği gözlenmiştir.

\section{Anahtar Kelimeler}

Nüfus Sosyolojisi, Koronavirüs, Pandemi, Covid-19, Gençlik Araştırması

1 Dr. Selman Salim KESGIN, Kızılay Akademi, E-posta: slmnkesgin@gmail.com, ORCID: 0000-0003-0034-2070, Muhammet Burkay DURAK, Kızllay Akademi, burkaydurak@hotmail.com, ORCID: 0000-0002-4754-0165 


\title{
Pandemic and Demography: The Perceptions and Attitudes towards COVID-19 Pandemic by Age Groups
}

\begin{abstract}
Becoming the major policy matter of the World since December 2019, the COVID-19 pandemic is a turning point in the world is history due to its social, political, and economic impacts. As a non-experienced situation by human beings in recent history, closure of schools, shops, prayers, and lock-down at home, it has huge impacts on people. States and non-state actors developed with various strategies to cope with the pandemic. Along with the pandemic, the policies developed to tackle it has impacts on society varying by the political, historical, cultural, economic structure of it. Aside from the global and national impacts, the pandemic also has enormous effects on the persons.

Considering this, the "Coronavirus Pandemic: Attitudes and Perception Survey" has been designed and implemented to observe the effects of a pandemic on persons and society. The computer-assisted web interview has implemented online and 37296 people have participated.

The aim of this article is to examine the perceptions, attitudes, behaviors for the pandemic on different age groups. The survey data has analyzed by age subgroups, discussed and interpreted with the recommendations.

According to survey data, there is no major difference among the different age-groups about the perception, attitudes, behaviors towards COVID-19 pandemic. However, the results have shown that as age increases, the negative effects of the pandemic increases.
\end{abstract}

\section{Keywords}

Coronavirus, Pandemic, Covid-19, Population Sociology, Youth Research 
Yeni keşfedilen bir tür koronavirüsün (SARS-COV-2) yol açtığı bulaşıcı bir hastalık olan ve 1 Aralık 2019'da Çin'in Wuhan şehrinde başlayan COVID-19 salgını, dünya tarihinin önemli dönüm noktalarından biri olmuştur. Virüsün yeni bir virüs türü olması, oldukça kolay ve hızlı yayılım göstermesi, tıp camiasının henüz aşı ve ilaç geliştirmediği bir hastalık olması ve hastalığın nasıl bir seyir izleyeceği konusundaki belirsizlikler; devletleri, toplumları ve bireyleri büyük bir belirsizlik ile baş başa bırakmıştır. Virüsün bulaştığı kişi sayısının hızla artması, bu belirsizliğe bir de panik halini eklemiştir. Kasım 2020 itibarıyla küresel ölçekte Amerika Birleşik Devletleri, Hindistan, Brezilya, Fransa ve Rusya başta olmak üzere salgının bulaştığı kişi sayısı, 50 milyonu aşmıştır (WHO, 2020). Virüsün bulaştığı ve hayatını kaybeden kişilerin sayısının da katlanarak artması dikkat çekici ve üzerinde ayrıca durulması gereken bir durumdur.

Ülkeler; sağlık politikaları ile kapasiteleri, ekonomik, idari ve toplumsal yapılarına göre farklılaşan çeşitli önlemlerle salgını yönetmeye çalışmakta ve salginın olumsuz etkilerini azaltmak için faaliyetlerini geliştirmektedir.

Türkiye'de ilk COVID-19 vakası, 11 Mart 2020 tarihinde tespit edilmiş olup bu tarihten itibaren aşamalı olarak çeşitli politikalar hayata geçirilmiştir. Bu kapsamda öncelikli olarak sağlık ve güvenlik önlemlerine ağırlık verilmiş, tüm okullar ve üniversitelerde eğitime ara verilmesi kararı alınmıştır. Salgının ülke içinde yayılımı arttıkça kademeli olarak yurt içi ve dışı uçuşlar durdurulmuş; akademik, kültürel etkinlikler iptal edilmiş ya da formatı değişmiş, kamu kurum ve kuruluşlarında çalışanlara yöne- lik idari izin, esnek çalışma yöntemleri (uzaktan çalışma, dönüşümlü çalışma) gibi imkânlar sağlanmış, şehirlerarası yolculuklar valilik iznine bağlanmış, 65 yaş üstü ve 20 yaş altı bireylere sokağa çıkma yasağ1 ilan edilmiş ve büyükşehirlerde belirli aralıklarla sokağa çıkma kısıtlaması ilan edilmiştir. Camilerde cemaatle namaza ara verilmiş, belirli günlerde herkes için sokağa çıkma yasağ 1 getirilmiştir.

Dünyanın farklı bölgelerinde çok sayıda ülke de benzer tedbirler almıştır. Sokakların, tarihi ve turistik yerlerin insansız fotoğraflarını gördüğümüz bu dönemde büyük şehirlerde hava kirliliği oranı düşmüş, ozon tabakasındaki tahribatın hızı azalmış, şehir merkezlerinde yaban hayvanları görülmüş olması gibi gelişmeler, insanların toplumsal aktivitelerindeki azalışın diğer göstergeleridir (Manuel A. Zambrano-Monserrate, 2020).

Pandemi ile mücadele konusunda kamu politikası geliştiricilerinin benimsediği en yaygın strateji, halk sağlığını korumak yaklaşımı olmuştur. Buna göre amaç, salgının bulaştı̆̆ kişi sayısını sağlık sisteminin kapasitesi içinde tutmak ve salgını yönetilebilir kılmaktır.

Bu uygulamalar neticesinde 2020 ilkbahar ve yaz dönemlerinde salgının görece kontrol altında tutulduğu, yönetilebilir bir şekilde ilerlediği görülmektedir. Fakat sonbaharın başlangıciyla birlikte COVID-19 bulaşan kişi sayısı ve ölüm oranlarında artış trendi tekrar yükselişe geçmiştir.

Salgının tıbbi etkilerine dair bu kısa bilgilerin ardından makalenin konusu olarak salgına yönelik alg1 ve tutumu incelemeden önce öne çıkan bazı tespitleri sunmak yerinde olacaktır. Bu tespitlerin ardından salgının farklı toplumsal grup- 
lara, demografik yapılara nasıl etkisi olduğu alt kırılmalarla birlikte incelenmeli ve tartışılmalıdır.

\section{Salgin, Toplumsal Hayat ve Demografi}

Salgına dair ulusal ve uluslararası ölçekte yayınlanan birçok veri ve geleceğe yönelik projeksiyon çalışmaları, salgının yönetimi açısından çok önemli olmakla birlikte onun sosyal hayata etkileri de ayrıca takip edilecek kadar önemlidir. Zira pandeminin yol açtığı sağlık krizi ve eve kapanma politikalarının sadece sağl1k alanına mahsus ve kapanma süresi ile geçerli olan etkilerinin olmadiğ1, sağlık dışı alanlarda ve uzun sürecek etkilerinin olacağı söylenebilir. Bu durum; farklı uzmanlarca büyük yeniden başlama (great reset) (WeForum, 2020), paradigma kayması (Continetti, 2020) gibi kavramsallaştırmalarla nitelendirilmektedir.

Salgın; kişisel, toplumsal, ulusal ve küresel düzeyde tüm anlamlandırma mekanizmalarımızı sarsan, hatta yıkıma uğratan bir olgu olarak hızla gelip hayatımızın tam merkezine yerleşmiştir. Salgının ilk aşamalarında olayın mahiyetini idrak etmekte zorluk yaşayan bireyler, toplumlar ve ülkeler; zamanla daha fazla bilgiye ulaştıkça konunun büyüklüğü, etkisi ve neler olabileceğini daha net görmeye başlamıştır. Erdoğmuş (2020)'un da belirttiği gibi sağlık başta olmak üzere ekonomik ve sosyal bakımdan ilk etkilerinin görülmeye başlandığı sonraki günlere yönelik sonuçlarını kestirmenin ise oldukça zor olduğu bir durumla karşı karşıya kalındı.

Salgin ile birlikte evrensel bir soruna dönüşen Covid-19 Pandemisi, risk faktörünü tüm toplumlar için görünür kılmıştır. Alışılagelmiş, yerleşmiş kimlik, kalıp, ilişki ve sınırları aşarak küresel ölçekte bir ölüm tehdidi olarak dünyaya yayılan salgin, insanlara ne kadar k1rılgan bir ortamda yaşadığını da ayrıca göstermiştir. Zira kıtlık ve savaşlar gibi birlikte insanlık tarihinde çok büyük etkileri olan salginlar, gelecekte de fark11 isimlerle hayatımızda olacaktır. Bu gerçekliğe rağmen dünyanın en büyük ekonomilerine sahip ülkelerin salgınla mücadelede ihtiyaç duyulan en temel koruma malzemelerini sağlamakta aciz duruma düşmesi ne kadar kırılgan bir toplumsal sistem içinde olduğumuzun bir göstergesidir.

Özcan'ın da belirttiği gibi insanlık, bugüne kadar edindiği birikimin ciddi bir kısmını farklı bir tarz ve form içerisinde yeniden üretmek zarureti ile karş1 karşıya bulunmaktadır. Şehir hayatı ve imardan nüfus hareketliliğine, çalışma düzeninden çevreye, eğitim, usul ve anlayışından inanç ve ibadet pratiğine, alışveriş şeklinden pazar alışkanlıklarına, kültür ve sanattan müzik ve tiyatroya, düğünden cenazeye, spordan eğlenceye, seyahat, insan ilişkileri, toplu iş görme, yemek ve sofra düzeni, siyaset yapma tarz1, toplant1, sempozyum, konferans, sevgi ve iletişim dili vb. kısacası hayatın ve insanın dokunduğu her alanla ilgili olarak insanlar kendilerine yeni imkânlar ve kulvarlar bulmak zorundadir (Özcan, 2020).

Gelinen noktaya bakıldığında COVID-19'un sağllk alanındaki etkilerinin yanı sıra hayatın tüm alanları üzerinde önemli etkileri olduğu gözlenmektedir. Zira ulusal ve uluslararası düzeyde hareketliliğin azalması hatta durma noktasına gelmesi; ekonomiden sanata, spordan günlük hayata kadar hayatımızın her anında yeni bir duruma işaret 
etmektedir. Yeni normal olarak adlandırabileceğimiz bu süreç; toplumlar, bireyler, kamu yönetimleri ve uluslararası kurumlar için önemli değişiklikler gerektirmektedir.

Özellikle beyaz yakalılar için iş hayatının büyük bölümünün eve taşınmış olması; hane içi yaşam pratikleri ve rol paylaşımı konusunda yeni durumlar ortaya çıkarmıştır. Örneğin Çitil'in (2020) ifadeleriyle yaşamın neredeyse tamamının eve taşınması, özellikle kadınların iş yükünü olağanüstü artmıştır. Kadınlar; temizlikten çocukların eğitimine, (...) pek çok konuda zaten koordinatörken şimdi fiilen icracı olmak durumunda kalmıştır.

Salgının etkilerine yönelik gerçekleştirdikleri araştırma çalışmasını yorumlayan Yorğun'un da belirttiği gibi “Salgın, küresel düzeyde neredeyse hepimizi ruhsal, fiziksel ve sosyal açıdan eşitleyerek sağlık, eğitim, gelir eşitsizliği, yoksulluk, işsizlik, göç, iklim krizi, temel insan ihtiyaçlarına erişim dâhil her alanda yeni farkındalıklar oluşturdu. Salgın; bir yönüyle bencilliği besledi, dayanışmayı azalttı, yalnızlığa, biyolojik olduğu kadar psikolojik sorunlara ve bilgi kirliliğine yol açtı, ölüm korkusunu bireysel olmaktan çıkarıp toplumsallaştırdı (AA, 2020).

Bireylerin toplulukların ve toplumların daha önce tecrübe etmediği türde bir afete maruz kalması, koronavirüs konusunda güncel bilgiyi takip etmeye motive etmektedir. Bu nedenle iletişim; salgın ile ilgili bilgi edinme, salgından korunma ve salgına karşı tutumları şekillendirme konularında büyük öneme sahiptir. Bu süreçte salgının görece yeni ve çok sıcak bir gündem konusu olmas1, çok yoğun bir iletişim trafiği ortaya çıkarmıştır. İletişim ile ilgili üzerinde durulması gereken bir diğer kavram da infodemidir. Dünya Sağlık Örgütü tara- findan yapılan tanıma göre bir nevi bilgi salgını olarak isimlendirilebilecek olan infodemi, insanlarm bir konu hakkında aşırı bilgiye maruz kalması ve bunun neticesinde ortaya çıkan bilgi kirliliği anlamına gelmektedir. Dünya Sağlık Örgütü, infodemi konusunda uluslararası sempozyum ve konferanslar organize ederek ülkeler arası tecrübe paylaşımını kolaylaştırma çabasındadır (WHO, 2020). İnfodemiye yönelik olarak bireysel ölçekte yapılabilecek olanlar; gündemi, güvenilir kaynaklardan asgari sıklıkta takip etmek, infodemiye karşı bilim insanlarının açıklamalarına itibar etmek, akıllı telefonlarda artan haber akışını, ekran karşısında geçirilen süreyi kısıtlamak olarak sıralanabilir (Çölümlü, 2020).

Bu nedenle, COVID-19 Pandemisi'nin toplum üzerindeki etkisinin gözlemlenmesi ve toplumsal trendler doğrultusunda politika tasarımları gerçekleştirilmesi önemlidir. Salgının sosyal etkilerini ve salgına yönelik algıları gözlemlemek adına yürütülmüş bazı araştırmaların öne çıkan bulguları şunlardır:

IPSOS tarafindan periyodik olarak yapılan "Koronavirüs Salgını ve Toplum Araştırması", vatandaşların kendileri veya aileleri için salgını ne kadar tehlikeli gördüklerini izliyor. İlk dönemde salgının, kendileri veya aileleri için çok tehlikeli olduğunu düşünenlerin oranı \%37 düzeyindeyken eylül ayında oranın $\% 60$ seviyesine kadar yükseldiği görülmektedir. Yine aynı araştırma; salgınla beraber her 10 bireyden 7'sinin 'kendisi', 6'sinın 'bilim', 5'inin ise 'din' konusuna daha fazla değer/önem verdiğini belirtmektedir (IPSOS, 2020).

Konda tarafindan belirli aralıklarla düzenli olarak gerçekleştirilen ve vatandaşların salgından korunma yöntemleri- 
ne odaklanan diğer bir araştırmanın mayıs ayı verilerine göre salgından korunma önlemlerine uyma oranı, mart ayına göre artış göstermektedir (KONDA, 2020).

\section{Yöntem}

Türkiye Kızılay Derneği'nin insani yardım ve ilgili alanlarda eğitim çalışmaları ile bilimsel araştırmalar yürüten birimi olan Kızılay Akademi, bir dizi araştırma ile Koronavirüs Pandemisi'nin etkilerini izlemektedir. Bu kapsamda yürütülen Koronavirüs Salgın Süreci Alg1 ve Tutum Araştırması, 16 Nisan-15 Mayıs 2020 tarihleri arasında 37.296 katılımc1 ile CAWI (internet anketi) metoduyla gerçekleştirilmiştir.

Araştırma ölçeğinin hazırlanması sürecinde eğitim, istihdam, insani yardım, sosyal hizmetler, araştırma, sektörlerinden tecrübeli uzmanlarla toplantılar gerçekleştirilmiş, sorular ve soru formuna dair diğer teknik detaylar belirlenmiştir. Anket, ilk olarak pilot uygulama ile test edilmiş ve gerekli güncellemelerin yapılmasını takiben internet mecralarından dolaşıma sokulmuştur.

Anket formu; herkesin erişebileceği bir şekilde paylaşıma açılmış, formun farklı sivil toplum kuruluşlarının dâhil olduğu duyuru platformları ile internet haber siteleri üzerinden yaygınlaştırılması yapılmıștır. Ayrıca Türk Kızılay Şubeleri, Genç Kızılay Teşkilatları da anketin tanıtımı ve duyurusu için kendi yerel bölgelerinde iletişim çalışması yürütmüștür.

37.296 kişinin katılımı ile gerçekleştirilen araştırma, Türkiye geneli için \%99 güven aralığı ve (-/+) \%1 hata payına sahiptir. Ayrıca TÜİK 3 bölgeleri düzeyinde de \%99 güven aralığı için en yüksek (+/-) $\% 5$ hata payına sahiptir (Akdeniz \%2, Batı Anadolu \%2, Batı Karadeniz \%3, Batı Mar- mara \%3, Doğu Karadeniz \%4, Doğu Marmara $\% 2$, Ege $\% 2$, Güneydoğu Anadolu \%3, İstanbul \%1, Kuzeydoğu Anadolu \%5, Orta Anadolu \%3, Ortadoğu Anadolu \%4).

Anket verileri, "SPSS for Windows" (23) programindan yararlanılarak analiz edilmiş, analizlerde de Anova, T-Testi, Crombach Alpha testleri yapılmıştır.

Ankete katılanların demografik özellikleri ve meslek bilgilerine göre dağıllmı şu şekildedir:

\begin{tabular}{|c|c|}
\hline Tablo 1 & \\
\hline $\begin{array}{l}\text { Araştırmaya Katılanların } \\
\text { Demografik Özellikleri }\end{array}$ & Değişken \\
\hline Yaş Grubu & Oran \\
\hline $15-20$ & $7,5 \%$ \\
\hline $21-34$ & $42,1 \%$ \\
\hline $35-44$ & $25,9 \%$ \\
\hline $45-54$ & $16,6 \%$ \\
\hline $55-64$ & $6,5 \%$ \\
\hline $\begin{array}{l}65+ \\
\text { Meslek }\end{array}$ & $1,4 \%$ \\
\hline Öğrenci & $18,7 \%$ \\
\hline Ev Hanımı & $4,3 \%$ \\
\hline Memur & $15,6 \%$ \\
\hline İşçi & $21,7 \%$ \\
\hline Emekli & $6,3 \%$ \\
\hline İşsiz & $7,8 \%$ \\
\hline İş Adamı/ Esnaf & $4,3 \%$ \\
\hline Kariyer Meslek & $19,4 \%$ \\
\hline Diğer & $1,9 \%$ \\
\hline Hanenizin Aylık Geliri & \\
\hline $0-2.500 \mathrm{TL}$ & $20,9 \%$ \\
\hline
\end{tabular}




\begin{tabular}{|l|l|}
\hline $2.501-4.000 \mathrm{TL}$ & $22,3 \%$ \\
\hline $4.001-5.500 \mathrm{TL}$ & $18,9 \%$ \\
\hline $5.501-7.500 \mathrm{TL}$ & $14,9 \%$ \\
\hline 7.501 - ve üzeri & $23,1 \%$ \\
\hline
\end{tabular}

Uygun örneklem (convenience sampling) yönetimiyle toplanan bu veri, nüfusun genelini temsil iddiasında değildir. İnternet tabanlı bir araştırma olması yönüyle doğal olarak toplanan veri internete erişimi olan, internet okuryazarlığı olan kesimlerin cevaplarına dayanmaktadır.

Araştırmanın bir diğer sınırlılığı da onun belirli bir zaman dilimindeki durumu yansıtmasıdır. "Covid-19 Salg1n Süreci” ifadesindeki süreç kelimesinin vurguladığı üzere araştırma, dinamik bir durumun bir kesitini ele almaktadır. Pandeminin birey ve toplum için birçok belirsizliklerle dolu olması, zaman geçtikçe yeni bilgilerle insanların bilgi, alg1 ve tutumunun değişeceği göz önünde bulundurulmalidir.

\section{Bulgular}

Araştırma bulguları; salgın sürecinde tercih edilen iletişim kanalları, salgın konusundaki algı, tutum ve salgının etkileri başlıkları altında incelenecektir.

\section{İletişim Kanalları}

Yukarıda da belirtildiği üzere salgın sürecinde iletişim kanalları, doğru mesajın doğru yöntemlerle iletilmesi hem halk sağlığı çalışmalarını kolaylaştırması açısından önemlidir hem de infodemi ile mücadele konusunda önemli avantajlar sağlamaktadır.

$\mathrm{Bu}$ neden katılımcıların hangi iletişim kanallarını tercih ettiğinin belirlenmesi önem arz etmektedir. Bu kapsamda katılımcılara "Yeni Koronavirüs Salgını hakkındaki gelişmeleri ve duyuruları en çok hangi kaynaklardan takip ediyorsunuz?” sorusu yöneltilmiş, katılımcıların birden fazla seçeneği seçmeleri de mümkün kılınmıștır.

Tablo 2 Yaş Gruplarına Göre Tercih Edilen İletişim Kanalları

\begin{tabular}{|l|l|l|l|l|l|l|}
\hline \multirow{2}{*}{\multicolumn{1}{|c|}{ İletişim Kanalı }} & \multicolumn{5}{c|}{ Yaş Grupları } \\
\cline { 2 - 7 } & $15-20$ & $21-34$ & $35-44$ & $45-54$ & $55-64$ & $65+$ \\
\hline Aile, Akraba, Arkadaş Çevresi & $4,2 \%$ & $4,1 \%$ & $3,1 \%$ & $2,4 \%$ & $2,6 \%$ & $3,3 \%$ \\
\hline Akademik Yayınlar & $3,7 \%$ & $5,4 \%$ & $4,7 \%$ & $4,9 \%$ & $5,4 \%$ & $4,8 \%$ \\
\hline Diğger & $0,2 \%$ & $0,4 \%$ & $0,4 \%$ & $0,4 \%$ & $0,5 \%$ & $0,7 \%$ \\
\hline Gazete, Dergi & $1,8 \%$ & $3,0 \%$ & $3,5 \%$ & $3,8 \%$ & $4,3 \%$ & $8,1 \%$ \\
\hline İlan, Broşür & $0,1 \%$ & $0,4 \%$ & $0,4 \%$ & $0,5 \%$ & $0,4 \%$ & $0,3 \%$ \\
\hline İnternet Siteleri & $24,8 \%$ & $26,3 \%$ & $26,6 \%$ & $25,4 \%$ & $22,8 \%$ & $20,3 \%$ \\
\hline Radyo & $0,3 \%$ & $1,0 \%$ & $1,5 \%$ & $1,3 \%$ & $1,3 \%$ & $0,9 \%$ \\
\hline Sosyal Medya & $27,1 \%$ & $25,8 \%$ & $21,3 \%$ & $18,2 \%$ & $16,0 \%$ & $10,7 \%$ \\
\hline Televizyon & $33,6 \%$ & $29,2 \%$ & $33,1 \%$ & $37,0 \%$ & $39,4 \%$ & $43,1 \%$ \\
\hline Whatsapp Grubu & $4,1 \%$ & $4,3 \%$ & $5,2 \%$ & $6,1 \%$ & $7,4 \%$ & $7,9 \%$ \\
\hline
\end{tabular}


Yeni Koronavirüs Salgını ile ilgili ülkemizde yapılan güncel duyurulardan haberdarlık oranınin ortalama \%91 düzeyinde ve oldukça yüksek olduğu görülmektedir. Haberdarlık düzeyi; bölge, yaş, cinsiyet ve meslek değişkenlerine göre önemli farklılıklar göstermezken eğitim düzeyi azaldıkça oran \%78'lere kadar düşmektedir. Yeni Koronavirüs Salgını hakkındaki gelişmelerin en çok televizyondan $(\% 32,5)$, internet sitelerinden $(\% 25,6)$ ve sosyal medya $(\% 22,5)$ mecralarından takip edildiği görülmektedir.

Pandemi, hayatın birçok alanında olduğu gibi iletișim alanında da dijital mecraların kullanma oranını etkilemiştir. Yaş gruplarına göre sosyal medya, internet siteleri ve televizyonu tercih etme konusunda farklılık olmadığı görülmektedir. Ancak ayrıntılarda dikkat çeken bazı sonuçlar vardır:
Örneğin yaş grubu arttıkça gazete ve Whatsapp gruplarmin tercih etme oranının arttığı ve televizyonun tercih edilme oranının azaldığı görülmektedir. 15-34 yaş aralığındaki katılımcıların gelişmeleri takip etmek için kullandığı ana kaynak televizyon olmakla birlikte diğer dijital mecralara da özel bir ilgisinin olduğu dikkat çekmektedir.

\section{Alg1}

Pandeminin toplumsal bellek, uzun ve kısa süreli ulusal tartışma konuları nezdinde tecrübi bir karşıllığının olmaması, bir diğer ifadeyle 21. yüzyılda karşılaşılan ilk küresel salgın olması; onun bireyler ve kitleler nezdindeki anlamının ne şekilde anlaşıldığını önemli kılmaktadır.

Katılımcılara "Aşağıdaki ifadelere katılma düzeyinizi 0-5 ölçeğinde belirtiniz." şeklinde soruduğumuz soruya verilen cevapların yaş gruplarına göre dağılımı şu şekildedir:

Tablo 3 Yaş Gruplarına Göre COVID-19 Pandemisi Hakkındaki İfadelere Katılma Düzeyi

Aşağıdaki ifadelere katılma düzeyinizi seçiniz. (1: Kesinlikle Katılmıyorum, 5: Kesinlikle Katılıyorum)

\begin{tabular}{|l|l|l|l|l|l|l|}
\hline & $\mathbf{1 5}-\mathbf{2 0}$ & $\mathbf{2 1 - 3 4}$ & $\mathbf{3 5}-\mathbf{4 4}$ & $\mathbf{4 5}$ - 54 & $\mathbf{5 5 - 6 4}$ & $\mathbf{6 5 +}$ \\
\hline $\begin{array}{l}\text { Yeni Koronavirüs hastalığ1 konu- } \\
\text { sunda kimlerin daha fazla risk al- } \\
\text { tında olduğuna dair bilgi sahibiyim }\end{array}$ & 4,45 & 4,46 & 4,33 & 4,32 & 4,26 & 4,22 \\
\hline $\begin{array}{l}\text { COVID-19 virüsünün hangi yollarla } \\
\text { bulaştığ1 konusunda bilgi sahibiyim. }\end{array}$ & 4,36 & 4,39 & 4,32 & 4,30 & 4,26 & 4,21 \\
\hline $\begin{array}{l}\text { Yeni Koronavirüs Salgını ile ilgili } \\
\text { Türkiye'de yapılan güncel duyuru- } \\
\text { lardan haberdarım. }\end{array}$ & 4,36 & 4,36 & 4,29 & 4,29 & 4,26 & 4,22 \\
\hline $\begin{array}{l}\text { COVID-19 virüsünün bana da bula- } \\
\text { şacağını düşünüyorum. }\end{array}$ & 3,07 & 3,30 & 3,31 & 3,29 & 3,32 & 3,21 \\
\hline $\begin{array}{l}\text { COVID-19 virüsü bulaşan insanlar- } \\
\text { daki belirtiler konusunda bilgi sa- } \\
\text { hibiyim. }\end{array}$ & 4,13 & 4,14 & 4,09 & 4,08 & 4,04 & 4,00 \\
\hline
\end{tabular}

\section{Yaş Grupları}




\begin{tabular}{|l|l|l|l|l|l|l|}
\hline $\begin{array}{l}\text { Çevremdeki kişilerin Yeni Ko- } \\
\text { ronavirüs hastalığı } \begin{array}{l}\text { hakkında } \\
\text { yeterli bilgiye sahip olduğunu } \\
\text { düşünüyorum. }\end{array}\end{array}$ & 3,14 & 3,09 & 3,26 & 3,34 & 3,37 & 3,50 \\
\hline $\begin{array}{l}\text { Çevremdekilerin Yeni Koronavirüs } \\
\text { Salgını'na karşı yeterli önlemleri } \\
\text { aldıklarını düşünüyorum. }\end{array}$ & 3,20 & 3,07 & 3,17 & 3,24 & 3,23 & 3,46 \\
\hline $\begin{array}{l}\text { Çalıştığım yerde hijyen kurallarına } \\
\text { uyulduğunu düşünüyorum. }\end{array}$ & 3,67 & 3,62 & 3,80 & 3,83 & 3,71 & 3,76 \\
\hline $\begin{array}{l}\text { Evimde şu anda yeterince gı̊da } \\
\text { maddesi olduğunu düşünüyorum. }\end{array}$ & 3,92 & 3,89 & 3,90 & 4,00 & 4,07 & 4,12 \\
\hline $\begin{array}{l}\text { Evimde şu anda yeterli hijyen mal- } \\
\text { zemesi olduğunu düşünüyorum. }\end{array}$ & 3,91 & 3,92 & 3,93 & 4,00 & 4,03 & 4,07 \\
\hline $\begin{array}{l}\text { Dışarıdan bir destek almadan evin } \\
\text { tüm ihtiyaçlarını kendimizin karşı- } \\
\text { laması mümkün görünmüyor. }\end{array}$ & 2,76 & 2,71 & 2,58 & 2,47 & 2,39 & 3,04 \\
\hline
\end{tabular}

Bu ifadeler; bireylerin bilgi sahibi olmas1, çevrenin bilgi sahibi olması ve kurallara uyması, bireyin tedbir ve kendine yeterliliği başlıkları altında kategorize edilebilir.

Buna göre genel olarak bakıldığında katılımciların kendilerinin salgin hakkında bilgi sahibi olduğu algisı (ort.=4,27) yüksek ama çevrelerindeki insanların bilgi sahip olduğu ve kurallara uyduğu konusundaki algıları (ort.=3,34) ise daha düşüktür. Katılımcıların tedbirli olma ve salgına karşın hazırlıklı olma algısı ise 3,74 düzeyindedir. Gençlerde ve eğitim düzeyi yüksek katılımcıların Koronavirüs hakkında yeterli bilgiye sahip olduğu algisının nispeten daha yüksek olduğu görülmektedir. 65 yaş üstü katılımcıların ise çevredeki kişilerin yeterli bilgiye sahip olduğu algısı gençlere göre daha yüksektir.

Koronavirüs hakkında bilgi sahibi olma ifadesine katılma düzeyinin 4.35 oranında, ancak hastalığın kendisine de bulaşacağı ifadesine katılma düzeyinin 3.25 oranında olması insanların salgından haberdar olmakla birlikte kendileri- ni bir şekilde muaf gördükleri şeklinde yorumlanabilir. Bu durum özellikle 1520 yaş arasında katılımcılarda en yüksek seviyededir. Perrotta ve arkadaşları (2020) tarafindan yapılan farklı ülkelerdeki katılımcıların salgına karşı tutumlarını karşılaştırmalı bir şekilde ölçen araştırmada da gençlerin kendilerine virüs bulaşma tehlikesini daha düşük düzeyde algıladıkları görülmektedir.

Dikkat çekici bir diğer durum da yaş arttıkça salgının kendisine de bulaşacağını düssenlerin oranının doğru orantılı olarak artmasıdır.

'Çevremdekilerin Yeni Koronavirüs Salgını'na karşı yeterli önlemleri aldıklarını düşünüyorum.' ifadesine katılım düzeyinde de dikkat çekici bir durum vardır. Diğer meslek dalları ile büyük fark olmamakla birlikte, bu ifadeye katılma oranı ortalamasının mesleğini iş̧i $(3,08)$ ve işsiz $(3.00)$ olarak belirten kat1lımcılar arasında en düşük olduğu görülmektedir. 
Her bir yaş grubundaki kişilerin kendilerinin virüs hakkında bilgi sahibi olduklarını düşünme düzeylerinin çevresindekilerin bilgi sahibi olduklarını düşünme düzeylerinden yüksek olduğu gözlenmiştir. Bu iki düşünce arasındaki en fazla fark 15-24 yaş arası kişilerdedir. Yani yaş küçüldükçe kendilerinin bilgi sahibi olduğunu ama çevresindekilerin yeterince bilgi sahibi olmadığını düşünenlerin oranı artmaktadır.

\section{Tutum}

Salgına karşı mücadelenin en önemli aracı, kişisel korunma yöntemleridir. Maske, mesafe, temizlik olarak da vurgu- lanan bu tedbirler, Sağlık Bakanlığı'nın ve diğer kurumların iletişim kanallarından da sikl1kla dile getirilmektedir. Bu tedbirlere uyma düzeyini gözlemlemek adına katılımcılara birden fazla seçeneği işaretleyebilecekleri belirtilerek tedbirlere uyma düzeyi ve tedbirlerin koruyuculuğuna dair düşünceleri ayrı ayrı şu şekilde sorulmuştur:

Yeni Koronavirüs Salgını'na karşı kendinizi nasil koruyorsunuz?

Aşağıdaki önlemlerin Yeni Koronavirüs Salgını'na karşı ne kadar etkili olduğunu düşünüyorsunuz?

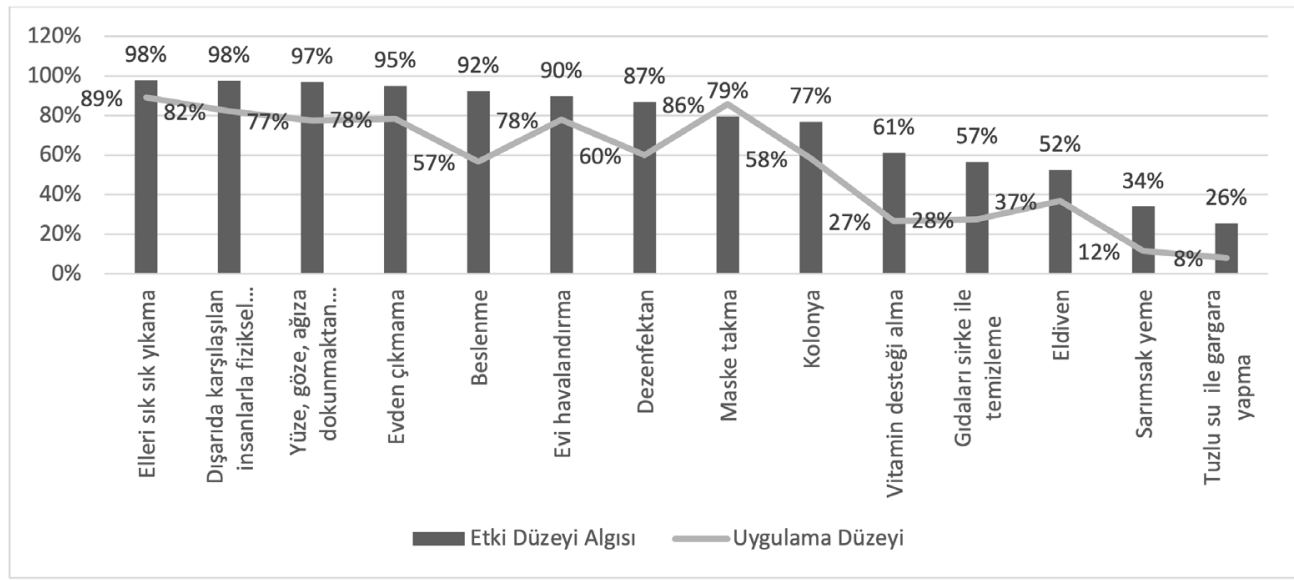

Şekil 1: COVID-19 Pandemisi'nden Korunma Tedbirleri Konularında Etki Düzeyi Algisı ve Uygulama Düzeyi

Cevaplar değerlendirildiğinde katılımciların Covid-19 Pandemisi konusunda genel bir bilgi yeterliliğine ulaştığ 1 görülmektedir.

Pandemiye karşı etkili olduğu düşünülen önlemler ve katılımcıların bu önlemleri uygulama düzeyleri karşılaştırıldığında maske kullanımı hariç her konuda seçilen tedbirin etkisine olan inan- cin uygulanmasından daha yüksek olduğu görülmektedir. Tek istisna olan maske kullanım oranının \%86 olduğu, maskenin etkili olduğunu düşünenlerin oranın (\%79) ise kullanım oranının altında olduğu görülmektedir.

Etki düzeylerine göre Yeni Koronavirüs Hastalığı'na karşı en az uygulanan korunma yolları ise beslenme, dezenfektan kul- 
lanımı, vitamin desteği ve gıdaların sirke ile temizlenmesidir. Buna karşın en çok uyulan korunma yolları ise el hijyeni, fiziksel mesafe, evi havalandırma, evden çık- mama ve yüze-göze-ağza dokunmamadır.

Farklı yaş gruplarına göre salgından korunma yöntemlerinin tercih edilme düzeyi aşağıdaki tabloda özetlenmiştir:

\begin{tabular}{|c|c|c|c|c|c|c|}
\hline \multirow{2}{*}{$\begin{array}{l}\text { Yeni Koronavirüs Salgını'na karşı } \\
\text { kendinizi nasıl koruyorsunuz? }\end{array}$} & \multicolumn{6}{|c|}{ Yaş Grupları } \\
\hline & $15-20$ & $21-34$ & $35-44$ & $45-54$ & $55-64$ & $65+$ \\
\hline Maske takarak & $9,4 \%$ & $10,9 \%$ & $11,3 \%$ & $11,3 \%$ & $11,5 \%$ & $9,8 \%$ \\
\hline Dezenfektan kullanarak & $7,0 \%$ & $7,6 \%$ & $7,9 \%$ & $8,0 \%$ & $7,6 \%$ & $7,1 \%$ \\
\hline Kolonya kullanarak & $8,2 \%$ & $7,8 \%$ & $7,4 \%$ & $7,0 \%$ & $6,6 \%$ & $7,1 \%$ \\
\hline Evi havalandırarak & $10,6 \%$ & $9,8 \%$ & $9,9 \%$ & $10,1 \%$ & $10,4 \%$ & $11,1 \%$ \\
\hline Vitamin desteği alarak & $3,2 \%$ & $3,4 \%$ & $3,5 \%$ & $3,4 \%$ & $3,5 \%$ & $3,4 \%$ \\
\hline Elleri sık sık yıkayarak & $11,8 \%$ & $11,3 \%$ & $11,4 \%$ & $11,6 \%$ & $11,7 \%$ & $12,7 \%$ \\
\hline $\begin{array}{l}\text { Yüze, göze, ağıza dokunmaktan ka- } \\
\text { çınarak }\end{array}$ & $9,4 \%$ & $10,0 \%$ & $10,0 \%$ & $10,0 \%$ & $9,8 \%$ & $9,4 \%$ \\
\hline Gıdaları sirke ile temizleyerek & $3,6 \%$ & $3,6 \%$ & $3,6 \%$ & $3,4 \%$ & $3,3 \%$ & $3,9 \%$ \\
\hline Eldiven takarak & $5,4 \%$ & $5,2 \%$ & $4,5 \%$ & $4,0 \%$ & $3,8 \%$ & $3,2 \%$ \\
\hline Beslenmeye dikkat ederek & $6,7 \%$ & $7,1 \%$ & $7,4 \%$ & $7,6 \%$ & $7,6 \%$ & $7,7 \%$ \\
\hline Evden dışarı çıkmayarak & $13,1 \%$ & $10,2 \%$ & $9,3 \%$ & $9,4 \%$ & $9,9 \%$ & $12,3 \%$ \\
\hline $\begin{array}{l}\text { Dışarıda karşılaşılan insanlarla fi- } \\
\text { ziksel mesafeyi koruyarak }\end{array}$ & $9,2 \%$ & $10,5 \%$ & $10,8 \%$ & $11,0 \%$ & $10,9 \%$ & $9,5 \%$ \\
\hline Sarımsak yiyerek & $1,3 \%$ & $1,4 \%$ & $1,6 \%$ & $1,6 \%$ & $1,6 \%$ & $1,5 \%$ \\
\hline Tuzlu su ile gargara yaparak & $1,0 \%$ & ,9\% & $1,1 \%$ & $1,2 \%$ & $1,2 \%$ & $1,1 \%$ \\
\hline Diğer & $0,2 \%$ & $0,2 \%$ & $0,3 \%$ & $0,4 \%$ & $0,4 \%$ & $0,5 \%$ \\
\hline
\end{tabular}

Korunma tedbirleri açısından yaş gruplarına göre büyük farklılık olmadığ1 görülmektedir. Bununla birlikte bazı hususlar dikkat çekicidir:

Salginla mücadele konusunda en çok vurgulanan tedbirler olan maske, mesafe ve temizlik konusunda maske ve mesafede yaşla doğru orantılı bir hassasiyet, temizlikte ise (büyük oranlarda ol- masa da) yaşla ters orantılı bir hassasiyet gözlenmiştir. Yani özelikle 15-24 yaş aralığındaki gençlerin maske takmanın salgından koruduğuna inancının ve maske takma pratiklerinin diğer yaş gruplarına oranla daha az olduğu gözlenmiştir. 1534 yaş arası katılımcıların evden dışarı çıkmama konusunda diğer yaş gruplarına göre daha yüksek oranda hassas 
olduğu ve eldiven kullanma oranlarının daha yüksek olduğu görülmektedir.

\section{Salgının Etkileri}

Salgının bireylerin, toplulukların ve toplumun günlük hayatlarına etkisi bu sürecin en önemli konularındandır. Zira insanlar; eğitim, din, kültür, çalışma hayatı başta olmak üzere birçok alanda daha önce tecrübe edilmemiş durumlarla karşı karşıya kalmıştır.

$\mathrm{Bu}$ durumu gözlemlemek amaciyla “Yeni Koronavirüs Salgını'nın size en önemli etkisinin ne olduğunu düşünüyorsunuz?" sorusu yöneltmiş ve verilen cevapların farklı yaş gruplarına göre dağılımı aşağıda sunulmuştur:

\begin{tabular}{|c|c|c|c|c|c|c|}
\hline \multirow{2}{*}{$\begin{array}{l}\text { Yeni Koronavirüs Salgını'nın size } \\
\text { en önemli etkisinin ne olduğunu } \\
\text { düşünüyorsunuz? }\end{array}$} & \multicolumn{6}{|c|}{ Yaş Grupları } \\
\hline & $15-20$ & 21-34 & $35-44$ & $45-54$ & $55-64$ & $65+$ \\
\hline $\begin{array}{l}\text { Alışkın olduğum sosyalleşme bi- } \\
\text { çimleri kısıtlandı }\end{array}$ & $33,8 \%$ & $31,1 \%$ & $29,4 \%$ & $29,6 \%$ & $32,0 \%$ & $35,4 \%$ \\
\hline Psikolojim bozuldu & $23,1 \%$ & $19,0 \%$ & $14,0 \%$ & $11,1 \%$ & $9,6 \%$ & $12,0 \%$ \\
\hline Ailemle daha fazla yakınlaştım & $17,5 \%$ & $14,8 \%$ & $18,6 \%$ & $20,4 \%$ & $20,1 \%$ & $16,7 \%$ \\
\hline Aylık gelirim azaldı & $7,7 \%$ & $13,7 \%$ & $16,0 \%$ & $14,1 \%$ & $11,4 \%$ & $8,4 \%$ \\
\hline İşimi kaybettim & $1,7 \%$ & $4,6 \%$ & $4,1 \%$ & $3,7 \%$ & $2,3 \%$ & $1,3 \%$ \\
\hline Hiçbir etkisi olmadı & $2,6 \%$ & $2,2 \%$ & $1,6 \%$ & $1,7 \%$ & $2,8 \%$ & $4,6 \%$ \\
\hline Sağlığımı kaybettim & $1,4 \%$ & $1,2 \%$ & $0,8 \%$ & $0,9 \%$ & $0,9 \%$ & $1,4 \%$ \\
\hline $\begin{array}{l}\text { Çevremdekilerle yardımlaşma } \\
\text { duygum gelişti }\end{array}$ & $9,1 \%$ & $10,5 \%$ & $13,0 \%$ & $16,0 \%$ & $18,0 \%$ & $18,1 \%$ \\
\hline Diğer & $3,1 \%$ & $2,9 \%$ & $2,6 \%$ & $2,6 \%$ & $3,0 \%$ & $2,0 \%$ \\
\hline
\end{tabular}

Katılımcılar, alışkın olduğu sosyalleşme biçimlerinin kısıtlanma $(\% 30,7)$, psikolojisinin bozulması (\%16), gelirinin azalması $(\% 13,7)$ ve işini kaybetmesi $(\% 3,9)$ gibi olumsuz etkilerinin yanı sıra ailesiyle daha fazla yakınlaşma $(\% 17,3)$ ve çevresindekilere karşı yardımlaşma duygusunun gelişmesi $(\% 12,5)$ gibi olumlu sayılabilecek etkilerinin olduğunu belirtmişlerdir.
"Psikolojim bozuldu" ifadesini seçenlerin oranının yaş azaldıkça artması, üzerinde durulması gereken bir diğer konudur. Ayrıca uzun süre evde kalmanın doğal bir sonucu olarak "Ailemle daha fazla yakınlaştım” diyenlerin oranının 35-64 yaş aralığında yoğunlaşmış olması dikkat çekmektedir. Yakınlaşma, yaşlilar ve gençlere oranla orta yaşlilarda daha fazladır. 
Salgının bir olumlu sonucu da insanları yardımlaşmaya motive etmesidir. Katılımcıların yaşla doğru orantılı olarak pandemi sürecinde yardımlaşma duygusunun geliştiğini ifade ettiği görülmektedir.

Karantina sürecinde insanlar daha önce olmadığı kadar evlerine kapanmıştır. Eve kapanmanin her toplumsal grup için farklı anlamı ve karşılığı vardır. Salgin sürecinde ekonomik sıkıntı yaşayan birisi ile yaşamayan birisi için "ev" aynı anlama gelmemektedir. Tıpkı dışarı çıkamadan sosyalleşme imkânı olmayan biri ile gün boyu sosyal medya ve oyun platformlarında aktif olan birisi için "ev "in aynı anlama gelmediği gibi

$\mathrm{Bu}$ tespitten hareketle katılımcıların karantina sürecinde evlerinde nasıl vakit geçirdiklerini gözlemlemek amacıyla "Evde kaldığınız sürede ne yapmak size iyi geliyor ve sizi rahatlatıyor?” sorusu yöneltilmiştir. Bu soruya verilen cevaplar şu şekildedir:

\begin{tabular}{|c|c|c|c|c|c|c|}
\hline \multirow{2}{*}{$\begin{array}{l}\text { Evde Kaldığınız sürede ne } \\
\text { yapmak size iyi geliyor ve } \\
\text { sizi rahatlatıyor? }\end{array}$} & \multicolumn{6}{|c|}{ Yaş Grupları } \\
\hline & $15-20$ & $21-34$ & $35-44$ & $45-54$ & $55-64$ & $65+$ \\
\hline Spor Yapmak & $6,0 \%$ & $5,7 \%$ & $5,4 \%$ & $6,0 \%$ & $7,0 \%$ & $9,1 \%$ \\
\hline Dua Etmek & $7,4 \%$ & $8,4 \%$ & $11,1 \%$ & $12,8 \%$ & $13,5 \%$ & $12,9 \%$ \\
\hline Meditasyon / Yoga Yapmak & $1,2 \%$ & $1,1 \%$ & $6 \%$ & $0,5 \%$ & $0,5 \%$ & $0,7 \%$ \\
\hline $\begin{array}{l}\text { Arkadaşlarımla / Akrabala- } \\
\text { rımla Telefon veya Internet } \\
\text { Üzerinden Sohbet Etmek }\end{array}$ & $10,4 \%$ & $9,9 \%$ & $10,2 \%$ & $10,7 \%$ & $11,9 \%$ & $12,3 \%$ \\
\hline $\begin{array}{l}\text { İnternette Vakit Geçirmek } \\
\text { (Sosyal M. vb.) }\end{array}$ & $12,3 \%$ & $11,6 \%$ & $11,4 \%$ & $11,0 \%$ & $11,5 \%$ & $11,6 \%$ \\
\hline Film Dizi İzlemek vb. & $12,8 \%$ & $12,8 \%$ & $12,6 \%$ & $11,9 \%$ & $10,9 \%$ & $9,7 \%$ \\
\hline Kitap Okumak & $10,1 \%$ & $10,1 \%$ & $10,6 \%$ & $11,4 \%$ & $12,5 \%$ & $13,2 \%$ \\
\hline $\begin{array}{l}\text { İşimle Alakalı Çalışmalar } \\
\text { Yapmak }\end{array}$ & $2,9 \%$ & $5,4 \%$ & $7,2 \%$ & $7,7 \%$ & $6,7 \%$ & $5,5 \%$ \\
\hline $\begin{array}{l}\text { Hobi ve Özel Zevklere Vakit } \\
\text { Ayırmak }\end{array}$ & $7,4 \%$ & $6,6 \%$ & $5,7 \%$ & $5,5 \%$ & $5,1 \%$ & $4,5 \%$ \\
\hline Uyumak & $10,2 \%$ & $8,4 \%$ & $7,2 \%$ & $6,5 \%$ & $6,3 \%$ & $5,5 \%$ \\
\hline Bilgisayar Oyunları Oynamak & $4,2 \%$ & $4,2 \%$ & $2,7 \%$ & $1,7 \%$ & $1,7 \%$ & $2,5 \%$ \\
\hline $\begin{array}{l}\text { Ev Temizliği ve Bakım İşle- } \\
\text { rini Yapmak }\end{array}$ & $6,7 \%$ & $7,7 \%$ & $8,0 \%$ & $7,7 \%$ & $6,9 \%$ & $6,5 \%$ \\
\hline $\begin{array}{l}\text { Yemek Yapmak ve Yeni } \\
\text { Tarifler Denemek }\end{array}$ & $8,2 \%$ & $7,5 \%$ & $6,6 \%$ & $5,9 \%$ & $4,6 \%$ & $4,8 \%$ \\
\hline Diğer & $0,5 \%$ & $0,6 \%$ & $0,8 \%$ & $0,8 \%$ & $1,0 \%$ & $1,1 \%$ \\
\hline
\end{tabular}


Katılımcılar, evde kaldıkları süreçte film izlemenin $(\% 12,5)$, internette vakit geçirmenin $(\% 11,5)$, kitap okumanin $(\% 10,6)$, telefon/internet üzerinden sohbet etmenin $(\% 10,3)$ ve dua etmenin (\%10) kendilerine iyi geldiğini/rahatlatt1ğını ifade etmiştir.

Yaş grubu arttıkça ve gelir durumu azaldıkça dua etme oranının arttığ görülmektedir. Bu durum insanların maneviyatla kurduğu ilişkiye etkileri açısından dikkat çekicidir. Spor yapma seçeneğini işaretleyenlerin büyük oranda yaşlılar olması da dikkat çekicidir.

Gençlerin en fazla tercih ettiği aktivitenin arkadaşlarımla/akrabalarımla telefon veya internet üzerinden sohbet etmek, internette vakit geçirmek (sosyal $\mathrm{m}$. vb.), film, dizi izlemek vb. uyumak olduğu görülmektedir. Görüldüğü üzere dijital temelli aktiviteler, insanların iyi olma haline katkı sağlayan temel aktiviteler olarak öne çıkmaktadır. İnternette günlük ortalama yedi saat, sosyal medyada ise yaklaşık üç saat geçirilen günlerde (AA, 2020), dijital platformlar dünya ile irtibatın en önemli mecrası olarak dikkat çekmektedir. 21. yüzyılda tecrübe ettiğimiz ve zaten günlük hayatımızın önemli bir bileşeni olan dijital dönüşüm, pandemi ile daha da hızlanmıştır ve muhtemelen salgın sonrasında alınacak tedbirler dijital dönüşümü hızlandıracaktır.

Üzerinde durulması gereken bir konu da dijitalleşmenin sadece bir baş etme stratejisi olarak mı ortaya çıktığı yoksa salgın sonrası sosyalleşme biçimlerimize de etkisi olacak olan yeni bir durum mu olduğudur. Geçer(2020)'in de belirttiği gibi mevcut dijital mecraları aşırı kullanmak; bizim görüşmek, sohbet etmek gibi sosyal ihtiyaçlarımı$\mathrm{z} 1$ azaltıyor mu acaba? Yoksa aslında sosyal medya kanallarını kullandığımız için uzun süreli fiziksel ayrılıklara alışık mıdık zaten? Diğer bir ifade ile çevrim içi görüşmeler bizim bu karantina sürecine adaptasyonumuzu arttıriyor mu? Örneğin insanlar WhatsApp haberleşme programı aracılı̆̆ıyla uzun süre bir yakı$\mathrm{n}$ ile görüşmekte ve bunu yeterli görüp yakınlarını tekrar ziyaret etmeye ya da aramaya ihtiyaç duymayabilmektedir.

Pandemi sürecinin en önemli bileşenlerinden biri gönüllü veya zorunlu olarak evde kalmak mecburiyetidir. Evde kalış sürecinin etkilerini gözlemlemek amacıyla katılımcılara "Yeni Koronavirüs Salgını nedeniyle evde kaldığınız süreçte sizi en çok zorlayan durumlar nelerdir?" sorusu yöneltilmiş ve cevapların yaş gruplarına göre dağılımı aşağıda sunulmuştur:

\begin{tabular}{|l|c|c|c|c|c|c|}
\hline Tablo 7 Yaş Gruplarına Göre Katılımcıları Zorlayan Durumlar \\
\hline $\begin{array}{l}\text { Yeni Koronavirüs Salgını nedeniy- } \\
\text { le evde kaldığınız süreçte sizi en } \\
\text { çok zorlayan durumlar nelerdir? }\end{array}$ & $\mathbf{1 5 - 2 0}$ & $\mathbf{2 1 - 3 4}$ & $\mathbf{3 5 - 4 4}$ & $\mathbf{4 5}-\mathbf{5 4}$ & $\mathbf{5 5}-\mathbf{6 4}$ & $\mathbf{6 5}+$ \\
\cline { 4 - 8 } & $40,9 \%$ & $31,6 \%$ & $23,1 \%$ & $26,9 \%$ & $38,2 \%$ & $52,8 \%$ \\
\hline Dişarı Çıkamamak & $3,7 \%$ & $3,3 \%$ & $11,4 \%$ & $10,1 \%$ & $3,6 \%$ & $1,2 \%$ \\
\hline $\begin{array}{l}\text { Çocukların Uzaktan Eğitimiyle } \\
\text { İlgilenmek }\end{array}$ & $8,0 \%$ & $7,8 \%$ & $6,8 \%$ & $5,9 \%$ & $4,3 \%$ & $5,7 \%$ \\
\hline Yemek, Temizlik vb. Ev İşleri & $13,6 \%$ & $17,9 \%$ & $14,2 \%$ & $13,2 \%$ & $10,9 \%$ & $5,7 \%$ \\
\hline Maddi Problemler & & &
\end{tabular}




\begin{tabular}{|l|c|c|c|c|c|c|}
\hline Aile İçi Gerginlik & $20,5 \%$ & $13,4 \%$ & $7,2 \%$ & $6,4 \%$ & $6,1 \%$ & $6,8 \%$ \\
\hline Çocukları Kontrol Etmek & $2,3 \%$ & $5,4 \%$ & $13,7 \%$ & $8,6 \%$ & $3,7 \%$ & $1,6 \%$ \\
\hline $\begin{array}{l}\text { Aile Büyüklerinin Yanında Olama- } \\
\text { mak }\end{array}$ & $5,2 \%$ & $14,3 \%$ & $19,7 \%$ & $22,3 \%$ & $22,1 \%$ & $11,2 \%$ \\
\hline Hiçbiri & $3,0 \%$ & $4,0 \%$ & $2,9 \%$ & $4,8 \%$ & $7,8 \%$ & $9,1 \%$ \\
\hline Diğer & $2,9 \%$ & $2,3 \%$ & $1,0 \%$ & $1,9 \%$ & $3,3 \%$ & $6,0 \%$ \\
\hline
\end{tabular}

Katılımcıları salgın sürecinde en çok zorlayan konuların başında dışarı çıkamamak $(\% 29,5)$, aile büyüklerinin yanında olamamak $(\% 16,9)$, maddi problemler $(\% 15,3)$ ve aile içi gerginlik $(\% 10,5)$ gelmektedir. 20 yaş altı ve 65 yaş üzeri kişileri en çok dışarı çıkamamak; orta yaş grubunu çocuklarla ilgilenmek, aile büyüklerinin yanında olamamak; 21-34 yaş grubunu ise en çok maddi problemler zorlamaktadır. Ayrıca aile içi gerginlikten en çok etkilenen grup da 20 yaş altı gruptur.

Öğrencileri dışarı çıkmamak ve aile içi gerginlik; ev hanımlarını çocuklarla ilgilenme ve ev işleri; işsizleri maddi problemler; kariyer meslek ve memurları aile büyüklerinin yanında olamamak diğer gruplara göre daha çok zorlamaktadır.

Pandeminin psikolojik etkilerini daha derinlemesine gözlemlemek adına katılımcılara "Salgın süresince kendinizde daha fazla geliştiğini düşündüğünüz yönler neler?” sorusu da yöneltilmiştir. Yaş gruplarına göre bu soruya verilen cevaplar şu şekildedir:

Tablo 8 Yaş Gruplarına Göre Katılımcıların Kendilerinde Daha Fazla Geliştiğini Düşündüğü Yönler

\begin{tabular}{|l|c|c|c|c|c|c|}
\hline \multirow{2}{*}{$\begin{array}{l}\text { Salgın süresince kendinizde } \\
\text { daha fazla geliștiğini düșün- } \\
\text { düğ̈ünüz yönler nelerdir? }\end{array}$} & \multicolumn{5}{|c|}{ Yaş Grupları } \\
\cline { 2 - 7 } & $\mathbf{1 5 - 2 0}$ & $\mathbf{2 1}-\mathbf{3 4}$ & $\mathbf{3 5 - 4 4}$ & $\mathbf{4 5}-\mathbf{5 4}$ & $\mathbf{5 5}-\mathbf{6 4}$ & $\mathbf{6 5}+$ \\
\hline İrade & $13,7 \%$ & $14,2 \%$ & $15,2 \%$ & $15,4 \%$ & $16,2 \%$ & $17,0 \%$ \\
\hline Tedbir & $17,3 \%$ & $21,3 \%$ & $25,0 \%$ & $26,6 \%$ & $27,9 \%$ & $27,1 \%$ \\
\hline Umut & $12,1 \%$ & $11,8 \%$ & $12,9 \%$ & $14,6 \%$ & $14,4 \%$ & $15,0 \%$ \\
\hline Azim & $8,2 \%$ & $8,3 \%$ & $9,1 \%$ & $10,3 \%$ & $11,1 \%$ & $11,4 \%$ \\
\hline Mizah & $4,5 \%$ & $3,6 \%$ & $3,1 \%$ & $3,6 \%$ & $3,4 \%$ & $3,5 \%$ \\
\hline Merak & $9,7 \%$ & $8,8 \%$ & $7,8 \%$ & $7,7 \%$ & $7,5 \%$ & $7,4 \%$ \\
\hline Öfke & $8,0 \%$ & $5,7 \%$ & $4,0 \%$ & $3,1 \%$ & $2,2 \%$ & $3,0 \%$ \\
\hline Umutsuzluk & $6,7 \%$ & $6,6 \%$ & $4,5 \%$ & $2,7 \%$ & $1,9 \%$ & $1,1 \%$ \\
\hline Endișe & $17,7 \%$ & $17,3 \%$ & $15,5 \%$ & $13,3 \%$ & $12,1 \%$ & $12,1 \%$ \\
\hline
\end{tabular}




\begin{tabular}{|l|l|l|l|l|l|l|}
\hline Tembellik & $1,3 \%$ & $1,6 \%$ & $1,9 \%$ & $1,7 \%$ & $1,7 \%$ & $1,2 \%$ \\
\hline Hiçbiri & $0,0 \%$ & $0,0 \%$ & $0,0 \%$ & $0,0 \%$ & $0,0 \%$ & $0,0 \%$ \\
\hline Diğer & $0,8 \%$ & $0,9 \%$ & $1,0 \%$ & $1,2 \%$ & $1,5 \%$ & $1,2 \%$ \\
\hline
\end{tabular}

Endişe ve tedbir kavramlarının gençlerin en fazla dile getirdiği ruh hali olduğu görülmektedir. Tedbir ve umut yönlerinin yaşla doğru orantılı olduğu; öfke, umutsuzluk, endişe duygularının yaşla ters orantılı olduğu görülmektedir.

Toplum ruh sağlığı açısından farklı demografik gruplar için evde geçirilen zaman ve meşgul olunan aktivitelerin derinlemesine analizi yapılmalıdır. Zira yaşanılan sürecin en önemli psikolojik etkisi derin bir güvensizlik ve belirsizlikle gelebilecek yaşamsal faaliyetlere yansıyacak anksiyete ve belki de sevdiklerini kaybedebilme korkusunun yaratacağ1 travmalar olarak görülebilir. Eve kapanma durumunda evde geçen sürenin ne zaman sona ereceğini bilememek ve evde kaliteli zaman geçirin diye sürekli insanları bir şeyler yapmaya zorlamak insanların korkularına yenisini eklemektedir.

Salgının olumsuz olarak nitelendirilebilecek etkilerinin gençlerde daha yoğun bir şekilde olmasının arkasında şu iki faktörün etkili olduğu söylenebilir. Eğitim çağındaki gençlerin eğitimlerinden, en önemli sosyalleşme ortamlarından uzakta kalması, iş piyasasındaki gençlerin de işlerini kaybetmesi ya da kaybetme tehlikesi altında olması. Acar'1n (2020) tespitleriyle salgının, eğitim, öğretim ve iş temelli öğrenmede aksamalara; iş arayan ve işgücü piyasasına yeni giren gençler için zorlukların artmasına ve istihdam kalitesinin düşmesine yol açmasına bağlı yaşanan/yaşanabilecek iş ve gelir kayıpları gibi nedenlerle gençler üzerindeki olumsuz etkisinin daha fazla olacağı beklenmektedir. Bu bağlamda; ekonomi ve istihdamı canlandırıcı, işletme, istihdam ve gelirleri destekleyici, gençleri koruyucu, sosyal diyaloğu geliştirici kapsamlı ve hedefli politika ve çözümler geliştirmek gerekmektedir.

\section{Sonuç}

20 Kasım 2020 itibarıla dünya genelinde 60 milyonu aşkın kişiye bulaşan, 1.4 milyonu aşkın kişinin ölümüne neden olan COVID-19 Pandemisi, insanlık tarihinin dönüm noktalarından biri olmuştur. Pandeminin tıbbi etkileri ve sonuçlarının yanı sıra hayatımızın her alanında bıraktığı kalıcı ve yapısal etkiler de onu ayrıca önemli kılmaktadır.

Refah düzeyi görece yüksek ülkelerin dahi sağlık sistemlerinde çöküntüye yola açan maske, korunma malzemesi gibi temel sağlık malzemelerin tedariki konusunda ülkeler arasında rekabete şahit olduğumuz pandemi süreci, toplumları ve devletlerin kırılganlığını tüm açıklığıyla göstermiştir. "Cahilliğimiz hakkında hiç bu kadar bilgi sahibi olmamıştık" diyen Habermas'tan (2020) mülhem bir şekilde pandemi bizlere zayıflığımızı ve kırılganlığımızı çok açık bir şekilde göstermiştir. Pandemi'den çıkardığımız dersleri ve günlük hayatımiza etkilerini bir arada ele alarak onun tıbbi, ekonomik, sosyal etkileri ile mücadele etmek ve kalıcı etkilerini de analiz etmek politika geliștirici ve uygulayıc1lar için büyük öneme sahiptir. 
Bu değerlendirmeler ışığında, 'geleceği kurgulamak için bugünü anlamak ve anlamlandırmak önemlidir' tespitinden hareketle gerçekleştirilen bu araştırma ile Koronavirüs Pandemisi'ne yönelik algılar ve tutumlar konusunda yaş gruplarına göre farklılık olup olmadığı incelenmiştir.

Yeni Koronavirüs Pandemisi hakkındaki gelişmeleri takip etmek için en çok kullanılan iletişim kanalının televizyon, internet ve sosyal medya mecraları olduğu gözlenmiştir. Ayrıca bu tercih sıralamasında yaş gruplarına göre farklılık olmadığı tespit edilmiştir.

Katılımcıların genel olarak Koronavirüs konusunda bilgi sahibi olduğu, korunma tedbirleri açısından bilgi düzeyinin yüksek olduğu ancak Koronavirüsün psikolojik etkileri ile başa çıkma konusunda daha fazla desteğe ihtiyaç duyduğu gözlenmiştir. Salgının psikolojik etkileri açısından gençlerin toplumun diğer sınıflarından belirgin bir şekilde ayrıştığı bir ruh hali gözlenmiştir. Buna göre gençlerin pandemi sürecinde psikolojilerinin daha çok etkilendiği, endişeli bir ruh haline büründüklerini tespit edilmiştir. Salgın sürecinde en çok zorlanılan durumun ne olduğu sorusuna "aile içi gerginlik" cevabını veren en büyük grubun da 15-20 yaş arasındaki katılımcılar olması bu durumu teyit etmektedir.

Araştırma sonuçları gösterdiği üzere toplumun, toplumsal grupların, bireylerin psikolojik dayanıklılığını sağlamak amacıyla psikososyal alanda uzmanlığı olan kamu kurumları ve sivil toplum kurumlarının bu konuyu ayrıca ele almaları önem arz etmektedir. Bu nedenle benzeri araştırmaların farklı toplumsal grupların alt kırılımlarını detaylı göz- lemleyecek metotlarla yapılması gereklidir. Belirsizliğin azalmaya başlamış olması pandeminin toplum üzerindeki etkilerinin gözlenmesini daha önemli hale getirmektedir.

\section{Kaynakça}

AA. (2020, 10 15). https://www.aa.com.tr/tr/bilimteknoloji/turkiyede-gunde-ortalama-7-saat-29dakika-internette-geciyor/1899392 adresinden alınd 1

AA. (2020, 10 10). https://www.aa.com.tr. https:// www.aa.com.tr/tr/koronavirus/turkiye-kovid-19lamucadele-performansiyla-dunya-ortalamasinafark-atti/1844671 adresinden alınd1

Acar, A. C. (2020). COVID-19 Krizinin. A. Ö.

Muzaffer Şeker içinde, Küresel Salgının Anatomisi: İnsan ve Toplumun Geleceği (s. 473-495). Ankara: TÜBA.

Continetti, M. (2020, 11 3). https://www.politico. com/news/magazine/2020/03/19/coronaviruseffect-economy-life-society-analysis-covid-135579 adresinden alınd 1

Çitil, A. (2020, 11 11). http://blog.ilem.org.tr/salginve-gelecek adresinden alındı

Çölümlü, G. M. (2020, 10 25). https://www. memorial.com.tr/saglik-rehberleri/yeni-normaleuyum-surecinde-infodemi-salginina-dikkat/ adresinden alındı

Erdoğmuş, N. (2020, 11 1). https://www.aa.com. tr. https://www.aa.com.tr/tr/analiz/kovid-19salgini-anlam-yikimina-mi-yoksa-yeni-biranlamlandirmaya-mi-yol-acacak-/1793925 adresinden alınd 1

Geçer, E. (2020, 10 05). https://trtakademi. net/koronavirus-kategori/salgin-sosyolojisi/ adresinden alındı

Habermas, J. (2020, 10 10). https://www.fr.de/ kultur/gesellschaft/juergen-habermas-coronaviruskrise-covid19-interview-13642491.amp.html?_ twitter_impression=true adresinden alınd 1 
IPSOS. (2020, 10 25). https://www.ipsos.com/ tr-tr/koronavirus-surecinde-her-10-bireyden-7sikendisine-6sibilime-5-i-ise-din-konusuna-dahafazla-deger adresinden alındı

IPSOS. (2020, 10 05). https://www.ipsos.com/tr-tr/ kontrollu-sosyal-hayat-maske-mesafe-ve-kisiseltemizlik-konusunda-kamuoyu-ne-dusunuyor adresinden alındı

KONDA. (2020, 11 10). https://konda.com. tr/wp-content/uploads/2020/06/KONDA_ KoronavirusBilgiNotu_5Haziran2020.pdf adresinden alındı

Manuel A. Zambrano-Monserrate, M. A.-A. (2020). Indirect effects of COVID-19 on the environment. Science of The Total Environment, 728. doi:https://doi. org/10.1016/j.scitotenv.2020.138813.

Naeem, F. M. (2020). Coping with COVID-19: urgent need for building resilience through cognitive behaviour therapy. Khyber MedUniv Journal, 1-3. doi: DOI: 10.35845/kmuj.2020.20194.

Özcan, A. (2020). Koronavirüs ve Kültürel Değişim . TRT Akademi, 6 (10) , 866-869.

Perrotta, D. G.-C. (2020, 10 10). Behaviors and attitudes in response to the COVID-19 pandemic: Insights from a cross-national Facebook survey. https://www.medrxiv.org/ content/10.1101/2020.05.09.20096388v2.full. pdf+html adresinden alınd 1

WeForum. (2020, 11 1). https://www.weforum.org/ focus/the-great-reset adresinden alındı

WHO. (2020, 11 13). https://www.who.int/ news-room/events/detail/2020/06/30/defaultcalendar/1st-who-infodemiology-conference adresinden alındı

WHO. (2020, 11 15). WHO. https://covid19.who.int/ table adresinden alınd 1

\section{Bildirimler}

Bu makale Kızılay Akademi'nin "Koronavirüs Salgın Süreci: Algı ve Tutum Araștırması” verilerine dayanılarak hazırlanmıștır. Anket uygulama sürecindeki katkılarından dolayı Türk Kızılay Genel Şubeleri’ne, Genç Kızılay’a teşekkür ederiz.

Araştırma geliştirme ve uygulama sürecindeki katkılarından dolayı Alpaslan Durmuş, Mustafa Otrar'a ve analiz sürecindeki katkılarından dolayı Vahap Olhan ve Hakkı Polat'a teşekkür ederiz.

Bu araştırma Kızılay Akademi için hazırlanmıştır ancak makalede sunulan yorumlar yazarların kendi görüşleridir.

Çıkar çatışması: Yazarlar, bu makalede çıkar çatışması olmadığını bildirmiştir.

Finansal destek: Yazarlar, bu çalışma için finansal destek almamıştır. 